\title{
LAUDATO SI**
}

THOMAS P. RAUSCH, S.J.

T. Marie Chilton Professor of Catholic Theology

Loyola Marymount University

Los Angeles, California, U.S.A.

trausch@Imu.edu

Keywords: Laudato Si; encyclical; Pope Francis

One of the many benefits of the first space flights to the moon in the late 1960s were beautiful pictures of planet Earth taken by the astronauts, that blue globe swathed in clouds and floating in the vastness of space. For many who saw them, the very perspective of those pictures changed their sense of our home-it seemed small, fragile even, and indeed, it is as we have learned. The earth is under threat from abuse and neglect, and we are responsible.

No one has addressed that more powerfully than Pope Francis in his encyclical on the environment, Laudato Si' (Francis, 2015). This long anticipated document is not primarily about climate change as is so often alleged, although climate change is one of the Holy Father's concerns. Rather, it is an encyclical on how to protect our "common home," or as St. Francis of Assisi would say, our Sister, Mother Earth, who now cries out to us because of the harm we have inflicted on her through our irresponsible use and abuse of the goods which God has endowed her with (2). ${ }^{1}$

Laudato $\mathrm{Si}^{\prime}$ is very long-246 paragraphs and 163 pages divided into six chapters-but its concreteness and lack of abstract jargon, unlike most encyclicals, makes it an easy read. Two particular themes are woven throughout: first, we belong to one human family, dependent on each

"A similar article appears as Chapter 28, "Our Fragile Home," in Thomas P. Rausch, The Slow Work of God: Living the Gospel Today (New York, NY: Paulist Press, 2017), pp. 193-201.

${ }^{1}$ Numbers in parentheses refer to paragraph numbers in Laudato si'. 
other, and are related to all other living beings; second, the ecological crisis calls for a fundamental change in our lifestyles.

\section{CHAPTER I: WHAT IS HAPPENING TO OUR COMMON HOME}

In Chapter 1 and throughout the encyclical, the Pope calls attention to how we have plundered and abused the earth, filling her with filth and waste, poisoning her atmosphere, cutting down her forests that purify her air, and polluting her life-giving streams and oceans that teem with living creatures. Each year, we generate millions of tons of waste, much of it non-biodegradable, toxic, or even radioactive (21). The poor are especially affected-people get sick from insecticides, fungicides, herbicides, and agro-toxins. There are many premature deaths (20), and children are especially vulnerable.

These problems are closely linked to a throwaway culture. Most of the paper we produce is thrown away and not recycled, and our industrial system has not developed the capacity to absorb and reuse the waste and by-products it generates. Think of the global pollution problems today-in some countries, for example, raw sewage runs out of houses and down the streets.

Or consider the acres of previously forested land in Alberta, Canada, which are now vast, desolate areas devastated in the search for oil from tar sands. Companies have to resort to alternate measures to extract the oil, such as surface mining (digging up the rock or sand covering the oil-laden sediment) or injecting steam to get it out of the earth. Doing so uses up an enormous amount of water, distributes toxic metals into the surrounding watershed, and, perhaps most importantly, leads to an estimated $14 \%$ higher level of greenhouse gas emissions compared to conventional oil because some natural gas must be burned simply to convert the bitumen into a usable form (Stromberg, 2014). According to the U.S. Department of Energy, these industrial processes produce more climate pollution than it does to extract and process oil the conventional way (Biello, 2013), while similar efforts in the United States are also polluting fields and streams with oil.

In 2012, an estimated 8.4 million people died from air, water, and land pollution, according to the Global Alliance on Health and Pollution: "pollution alone kills three times more people than HIV, malaria, and tuberculosis combined" (Global Alliance on Health and Pollution, 2014). According to the World Health Organization, seven million people die annually from air pollution alone. Many also do not have access to safe 
drinking water, which the Pope notes is being turned into a commodity. We forget that it is not just American tourists who get sick from the water in Mexico; millions of children suffer from the same problem, and more than 1,600 of them die every day from diseases caused by drinking unsafe water. Given that access to safe drinking water is a basic human right, not something subject to the laws of commerce (30), Francis rightfully asks if we no longer have any concern for coming generations (161).

Francis also points to a "very solid scientific consensus" on the warming of the climatic system (23), caused primarily by the concentration of greenhouse gases that are generated from human activity. Recent studies show that these gases (carbon dioxide, methane, nitrogen oxides, and others) are concentrated in the atmosphere and do not allow the warmth of the sun's rays reflected by the earth to disperse in space. We need to replace highly polluting fossil fuels progressively, especially coal and oil (165), for their intensive use only aggravates the problem (23). This is not new teaching-Pope Paul VI, Pope John Paul II, and Pope Benedict XVI all called for policies to mitigate greenhouse gas emissions and assist those most affected by the harmful effects of climate change. Africa, in particular, is especially vulnerable (51). The abuse of the environment affects us all, especially the poor, such as that quarter of the world's population that lives on or near coastlines, and it contributes to the massive migration taking place today.

Francis praises the efforts of the international community to address these issues, citing the 1992 Earth Summit in Rio de Janeiro which spoke of the whole earth as an ecosystem, the 1972 Stockholm Declaration, the Basel Convention on hazardous wastes, and the Vienna Convention on the protection of the ozone layer. However, he notes that the 2012 Conference of the United Nations on Sustainable Development in Rio de Janeiro issued a wide-ranging but ineffectual document, reminding countries that they must not place their national interests above the global common good (169). One hopeful sign, on the other hand, was the 2015 United Nations Climate Change Conference in Paris where China played an important role.

Francis's encyclical addresses every person living on the planet, thereby speaking to other churches and Christian communities, religions, and all people of good will. He is concerned that we are exploiting the rich resources of our planet. With thousands of plant and animal species disappearing every year, he says that because of us, so many creatures "will no longer give glory to God by their very existence" (33). Therefore, while acknowledging that the Church does not have all the answers, he calls repeatedly for dialogue (61). He wants to draw on the best scientific research available to us today (15), but emphasizes that saving the planet 
involves all of us and not just the scientific community: "Our goal is not to amass information or to satisfy curiosity, but rather to become painfully aware, to dare to turn what is happening to the world into our own personal suffering and thus to discover what each of us can do about it" (19). The Pope is calling all people to a profound conversion, to a new vision, one that contemplates the threatened beauty of our earth, and to see also the faces of the poor who are most affected by climate change.

\section{CHAPTER II: THE GOSPEL OF CREATION}

Chapter II, where this Jesuit pope is at his most Franciscan, is especially beautiful. The encyclical echoes the Bible in teaching about the immense dignity of each person, created in the image and likeness of God and declared good by the Creator. From a Biblical perspective, the Pope argues that human life is grounded in three fundamental and closely intertwined relationships: our relationships with God, with our neighbor, and with the earth itself. These three vital relationships have been broken, however, both outwardly and within us, and Genesis 3 sees this rupture as the result of sin, the sin of our presuming to take the place of God and refusing to acknowledge our creaturely limitations. Francis argues that the Bible has no place for a tyrannical anthropocentrism at the expense of, or unconcerned for, God's other creatures, and refers specifically to his namesake, Francis of Assisi, who celebrated a harmony with all of them (66-68). Ecologists, long skeptical of anthropocentrism at the expense of the environment, have been delighted with this emphasis.

We cannot address the problems of our planet without reshaping our relationships with God, our neighbors, and the earth itself. From a Christian perspective, the Pope's vision here is profoundly Trinitarian: God is not a distant, solitary watch-maker but a loving Father who brings all things into being through the Word and fills creation with his life-giving Spirit. The earth, therefore, is not our own; we do not have absolute dominion over that which belongs to God alone. We are caretakers, not owners (75).

According to Peter Cardinal Turkson, a major force behind Laudato Si', "the word 'stewardship' only appears twice" in the encyclical while the word "care" appears dozens of times (EcoJesuit, 2015). Naomi Klein says that this is no accident-while stewardship speaks about a relationship based on duty, "when one cares for something it is something one does with passion and love" (Klein, 2015). This means a change in our way of 
thinking, for, as Fr. Seán McDonagh, also part of the drafting team for the encyclical, said, "We are moving to a new theology." He translates a Latin prayer that was once commonly recited after Communion during the season of Advent as an example: "Teach us to despise the things of the earth and to love the things of heaven" (Klein, 2015), and cautions that overcoming centuries of loathing the corporeal world is no small task.

In speaking of evolution, Francis notes the "sheer novelty involved in the emergence of a personal being within a material universe," suggesting the action of God and a particular call to life on the part of a "Thou" who also addresses human beings in this highly personal way (81). He writes that it "is clearly inconsistent to combat trafficking in endangered species while remaining completely indifferent to human trafficking, unconcerned about the poor, or undertaking to destroy another human being deemed unwanted" (91).

\section{CHAPTER III: THE HUMAN ROOTS OF THE ECOLOGICAL CRISIS}

Chapter III stresses the human roots of the ecological crisis. Francis calls not just for a heightened environmental consciousness but also for a substantial change in the way we live, which means changing our lifestyles, habits of consumption, and methods of production. All these contribute to climate change, which is a global problem with environmental, social, and economic consequences. Here the Pope is radically challenging the outlook we inherited from our culture!

Francis recognizes the contributions that technology has made to human flourishing, and his enumeration of modern inventions and scientific advances makes it clear that he is not against science or technology (102). Techno-science, when properly directed, can improve the quality of human life-who can deny, he says, the beauty of an aircraft or a skyscraper (103)? At the same time, however, Francis echoes a constant theme of Benedict XVI (located, for example, in the latter's encyclical on hope, Spe Salvi)_- "that scientific and technological progress cannot be equated with the progress of humanity" (113). He warns especially about the risk of tremendous power resting in the hands of a few: "The fact is that 'contemporary man has not been trained to use power well' because our immense technological development has not been accompanied by a development in human responsibility, values and conscience" (105).

Despite all this, we tend to believe that every increase in power means an increase in progress, which is not necessarily true. We have not been taught to use power well, or to recognize the great responsibility 
that goes with it. We assume that there is an infinite supply of the earth's goods, while a technocratic paradigm assumes that every advance in technology is for profit without paying attention to its potentially negative impact on human beings (109). We need to keep the larger picture in mind:

Ecological culture cannot be reduced to a series of urgent and partial responses to the immediate problems of pollution, environmental decay and the depletion of natural resources. There needs to be a distinctive way of looking at things, a way of thinking, policies, an educational program, a lifestyle and a spirituality which together generate resistance to the assault of the technocratic paradigm. (111)

For Francis, a modern anthropocentricism means that we neglect to monitor the harm done to nature, or to acknowledge the reality of the poor person or one with disabilities. He speaks of the value of work, indeed of our vocation to work, which is part of the meaning of life (128), and cautions against an unbridled free-market economy (129) and "indiscriminate genetic manipulation" (131).

\section{CHAPTER IV: INTEGRAL ECOLOGY}

Most important is the encyclical's basic point that as human beings we belong to one single human family, dependent on each other and on the earth that is our common home. As the Pope repeats many times, all things are connected and dependent on one another $(16,42,70,89)$ :

Time and space are not independent of one another, and not even atoms or subatomic particles can be considered in isolation. Just as the different aspects of the planet-physical, chemical and biological-are interrelated, so too living species are part of a network which we will never fully explore and understand. A good part of our genetic code is shared by many living beings. (138)

We need to be in solidarity with each other and care for the earth, not exploit it, for it and its fruits represent a shared inheritance and are meant to benefit everyone. We need a social perspective, one that is especially mindful of the rights of the poor and the underprivileged (93).

Nature is not something separate from us; we are parts of a network which we will never fully understand, one in which we share a genetic code with many living beings (139). We are becoming more aware of the importance of how different creatures relate to one another in making up 
the larger units we call "ecosystems" which we depend on for our own existence. "Sustainable use" thus means considering each ecosystem's regenerative ability (140), pointing to how they "interact in dispersing carbon dioxide, purifying water, controlling illnesses and epidemics, forming soil, breaking down waste, and in many other ways which we overlook or simply do not know about" (140).

Francis is challenging all to a profound conversion, to a change of lifestyle, and to adopt what he calls an "integral ecology" that goes beyond biology alone to take us to the heart of what it means to be human (10-11, 137). Those who ridicule expressions of concern for the environment or are passive need an "ecological conversion" so that their encounter with Christ becomes evident in their relationship with the world around them (217). They need to come to an integral ecology, one that respects both its human as well as social dimensions.

Nature can no longer be regarded as a mere setting in which we live. We are part of it, included in it, and in constant interaction with it. Nor can we continue to ignore the poor-Francis writes that "a true ecological approach always becomes a social approach; it must integrate questions of justice in debates on the environment, so as to hear both the cry of the earth and the cry of the poor" (49, emphasis in original). The environmental crisis, for example, affects nature and society, the social and the environmental (139). What Benedict XVI called "human ecology" is thus inseparable from the principle of the common good, the central and unifying principle of social ethics (156). It includes being concerned about lack of housing, public transportation, and extreme poverty.

When I see films on global poverty, and realize that those disadvantaged peoples are also seeing films about our affluence, I wonder what will happen when they demand for their fair share, and fear for the future.

\section{CHAPTER V: LINES OF APPROACH AND ACTION}

The Pope acknowledges that international conferences and dialogue have moved the ecumenical agenda forward. We are more conscious of our interdependence, and are aware of the need to replace our ways with more sustainable practices and that an "ecological debt" exists between the global North and South due to commercial imbalances (51). Those nations that have benefited from industrialization at the cost of an enormous increase in greenhouse gases have a greater responsibility 
toward providing a solution. Poor countries, on the other hand, need to develop less polluting forms of energy production, but they need the assistance of wealthy countries, some of which have "scandalous" levels of consumption after having experienced great growth at the cost of ongoing pollution. The solidarity of all peoples is key (172); we cannot leave the poor to pay the price (170).

Thus, while Francis acknowledges that the Church does not presume to answer scientific questions, he is concerned about honest debate that brings politics and the economy into dialogue. The environment will not be safeguarded by a free market and profit driven economy (190), yet he is calling not for an end to capitalism but for a spirituality more sensitive to our hurting planet. For instance, we may have to accept decreased growth in some parts of the world so that poorer regions may begin to flourish (193). He calls for a new, integral, and interdisciplinary approach to politics, one which will no longer tolerate organized crime, human trafficking, the drug trade, and violence. Moreover, given that majority of the world's population profess to be believers, religion also has its own role to play, particularly in opening new horizons.

\section{CHAPTER VI: ECOLOGICAL EDUCATION AND SPIRITUALITY}

In the final chapter, Francis calls on all to set forth on the long path of renewal, especially to a change of lifestyle (206) or, in religious terms, a conversion. He challenges what he calls the "myths" of modernity, that is, individualism, the myth of ongoing progress, consumerism, and unregulated free-markets (210). For instance, many young people in the most affluent countries are aware of a need for change but have grown up in a milieu of extreme consumerism. These are characteristic themes for Francis-in his 2013 encyclical Evangelii Gaudium, he pronounced a firm "no" to an economy of exclusion, inequality, and

trickle-down theories which assume that economic growth, encouraged by a free market, will inevitably succeed in bringing about greater justice and inclusiveness in the world. This opinion, which has never been confirmed by the facts, expresses a crude and naïve trust in the goodness of those wielding economic power and in the sacralized workings of the prevailing economic system. (Francis, 2013)

In Laudato Si', he contrasts such a "utilitarian mindset," characterized by consumerism, competition, and an unregulated market, with an environmental education that seeks to recover levels of ecological equilibrium with one's self, in solidarity with others, and with God. 
Environmental education should strive to embrace the transcendent that gives environmental ethics their deepest meaning (210). At the same time, it should help develop an "ecological citizenship" that encourages us to reduce water consumption, separate refuse, cook only what can reasonably be consumed, use public transportation or car-pooling, plant trees, turn off unnecessary lights, and so on (211). We can each do something.

Moreover, the care for nature includes a capacity for living together and in communion with others, in a kind of "universal fraternity" (228). Francis beautifully says that the "universe unfolds in God, who fills it completely. Hence, there is a mystical meaning to be found in a leaf, in a mountain trail, in a dewdrop, in a poor person's face" (233). "At the end, we will find ourselves face to face with the infinite beauty of God" (243).

\section{CONCLUSION}

Francis's encyclical is both poetic and practical: he reminds all to say grace before meals while noting that our food comes from the earth (227). Running throughout are the strategic principles of gradualism and incrementalism - we cannot solve everything at once, yet we need to get started. He stresses repeatedly the importance of dialogue, and that more dangerous than a doctrinal relativism is a practical relativism which gives absolute priority to our immediate convenience. Interestingly enough, he avoids the language of a culture of life and a culture of death, so often used by John Paul II.

Francis is also striving to speak for the whole Church; he does not want to be a solitary voice. He thus cites bishops' conferences from around the world more than twelve times, including those of Brazil, New Zealand, Southern Africa, Bolivia, Portugal, Germany, Argentina, the Dominican Republic, the Philippines, Australia, and the United States, among others. For example, these beautiful words come from the Roman Catholic Bishops' Conference of the Philippines: "Who turned the wonderworld of the seas into underwater cemeteries bereft of color and life?" This citing of bishops' conferences is in contrast with John Paul II and Benedict XVI who did not cite their teaching authority as much.

The Fathers of the Church said that the poor man has the right to take from those who have more than they need for his own needs (Paul VI, 1965: 69). The Pope's Roman Catholic and communitarian sensibility, obvious throughout the encyclical, continues this line of 
thought. Francis writes that the fruits of the earth are meant to benefit everyone, that the climate, our atmosphere, and the earth's natural resources are goods held in common, "belonging to all and meant for all" (23). He argues that the Christian tradition has never recognized the right to private property as absolute or inviolable, and has stressed the social purpose of all forms of such property (93). Similarly, he also rejects the idea that national sovereignty is an absolute right, and stresses that we need global regulatory norms instead (173). I wonder how many would welcome his teaching today.

Advancing Roman Catholic tradition while staying rooted in it, Laudato Si' is based not on new teaching but on the Church's social tradition, particularly in its emphasis on the common good and the dignity of the human person. Francis stresses a consistent ethic of life, saying that it is inconsistent to work to preserve animal species without at the same time being concerned about human trafficking or while being indifferent to the needs of the poor or those "deemed unwanted" (91). For instance, arguing that "concern for the protection of nature is also incompatible with the justification of abortion," he asks, "How can we genuinely teach the importance of concern for other vulnerable beings ... if we fail to protect a human embryo?" Quoting Benedict XVI, he says that if "personal and social sensitivity towards the acceptance of the new life is lost, then other forms of acceptance that are valuable for society also wither away" (120).

Francis therefore has some cautions. He rejects population control as a means to address the environmental crisis, stressing the unique difference between humans (transcending biology) and animals, even allowing experimentation on animals if it can contribute to saving human lives. He argues that gendered differences should be respected, and differentiates God from creation, which in the Eucharist is "projected towards divinization ... towards unification with the Creator himself" (236). The Pope's eucharistic vision here is deeply Roman Catholic.

A Christian spirituality should encourage a prophetic and contemplative lifestyle; it should not be obsessed with consumption (222). Francis's encyclical Laudato $\mathrm{Si}^{\prime}$ is a beautiful meditation on the damage we are doing to our Sister Earth, and a call to the conversion necessary to save our common home. St. Francis of Assisi could not have said it better! 


\section{REFERENCES}

Biello, D. 2013. How much will tar sands oil add to global warming? Scientific American, January 23. Available at https://www.scientificamerican.com/article/ tar-sands-and-keystone-xl-pipeline-impact-on-global-warming/.

EcoJesuit. 2015. Full text of the presentation of Cardinal Peter Kodwo Appiah Turkson. June 19. Available at http://www.ecojesuit.com/full-text-of-thepresentation-of-cardinal-peter-kodwo-appiah-turkson/7995/.

Francis. 2013. Evangelii gaudium. Vatican City: Libreria Editrice Vaticana.

Francis. 2015. Laudato si': On care for our common home. Vatican City: Libreria Editrice Vaticana.

Global Alliance on Health and Pollution. 2014. New analysis points to pollution as the largest cause of death in low-and middle-income countries. June 13. Available at http://www.gahp.net/new-analysis-points-pollution-largest-causedeath-low-middle-income-countries/.

Klein, N. 2015. A radical Vatican? The New Yorker, July 10. Available at http://www. newyorker.com/news/news-desk/a-visit-to-the-vatican.

Paul VI. 1965. Gaudium et spes. Vatican City: Libreria Editrice Vaticana.

Stromberg, J. 2014. Mining tar sands produces much more air pollution than we thought. Smithsonian.com, February 3. Available at http://www. smithsonianmag.com/science-nature/mining-tar-sands-produces-much-moreair-pollution-we-thought-180949565/. 